\title{
The Dark Side of Cell Fusion
}

\author{
Daniel Bastida-Ruiz ${ }^{\dagger}$, Kylie Van Hoesen ${ }^{\dagger}$ and Marie Cohen ${ }^{*}$ \\ Department of Gynecology Obstetrics, Faculty of Medicine, University of Geneva, Geneva 1211, Switzerland; \\ daniel.bastida@etu.unige.ch (D.B.-R.); kylie.vanhoesen@gmail.com (K.V.H.) \\ * Correspondence: marie.cohen@hcuge.ch; Tel.: +41-22-37-24-381 \\ + These authors contributed equally to this work.
}

Academic Editor: Lajos Kemény

Received: 29 March 2016; Accepted: 22 April 2016; Published: 28 April 2016

\begin{abstract}
Cell fusion is a physiological cellular process essential for fertilization, viral entry, muscle differentiation and placental development, among others. In this review, we will highlight the different cancer cell-cell fusions and the advantages obtained by these fusions. We will specially focus on the acquisition of metastatic features by cancer cells after fusion with bone marrow-derived cells. The mechanism by which cancer cells fuse with other cells has been poorly studied thus far, but the presence in several cancer cells of syncytin, a trophoblastic fusogen, leads us to a cancer cell fusion mechanism similar to the one used by the trophoblasts. The mechanism by which cancer cells perform the cell fusion could be an interesting target for cancer therapy.
\end{abstract}

Keywords: cancer; cell fusion; metastasis; drug resistance; syncytin

\section{Introduction}

Cancer progresses through the accumulation of genetic alterations [1] and chromosomal instability [2] among various other factors. Tumor cells have been known for decades to have the capacity to fuse with each other and with non-tumor cells, but how the fusion of tumor cells drives the biology of cancer is not yet very clear [3]. Cell fusion has recently gained a great deal of attention for its role in cancer progression as a source of genetic instability, as well as a mechanism of metastasis and drug resistance [3,4]. Cell fusion, the topic of discussion in this review, occurs when cell membranes merge and the cytoplasm is mixed, forming multinucleated cells [5]. Cancer cells can fuse with normal cells (stromal, epithelial, macrophages), and with other cancer cells. Depending on the cell type in the fusion event, the hybrid has novel properties [6] and increased heterogeneity [7]. Cancer cells that fuse together can contribute to the formation of polyploid giant cancer cells (PGCCs), which are highly tumorigenic and chemoresistant [8]. Cancer metastasis can be initiated by the fusion of cancer cells and macrophages [4].

An immediate result of cell fusion is polyploidy. Polyploid cells are defined as having genomes with multiples of the typical diploid $(2 \mathrm{n})$, such as $4 \mathrm{n}$ or $8 \mathrm{n}[9,10]$. Polyploidy is common in plants, but it is rare to find whole-body polyploidy in mammals. However, polyploidy is found in some mammalian tissue as a part of normal development and differentiation [11], including skeletal muscle, heart, placenta, liver, brain and blood cells [10]. On the other hand, polyploidy cells can form in mammals from stress, aging, and disease [12].

Polyploidy is associated with disease, such as cancer (Figure 1), because polyploid cells are genetically unstable due to the abnormal number of chromosomes. Polyploidy is an intermediate karyotype that often occurs between healthy diploid cells and neoplastic aneuploidy cells $[7,10,13,14]$. Aneuploidy is the presence of an abnormal chromosome number that deviates from the typical diploid number caused after the subsequent divisions of the polyploid cell, and is frequently observed in human cancer cells [12]. Cancers that have experienced a genome doubling (tetraploidy) have 
more chromosomal instability compared to diploid cancers, and in the majority of colorectal cancer, tetraploidization occurs as an early event $[7,15]$.

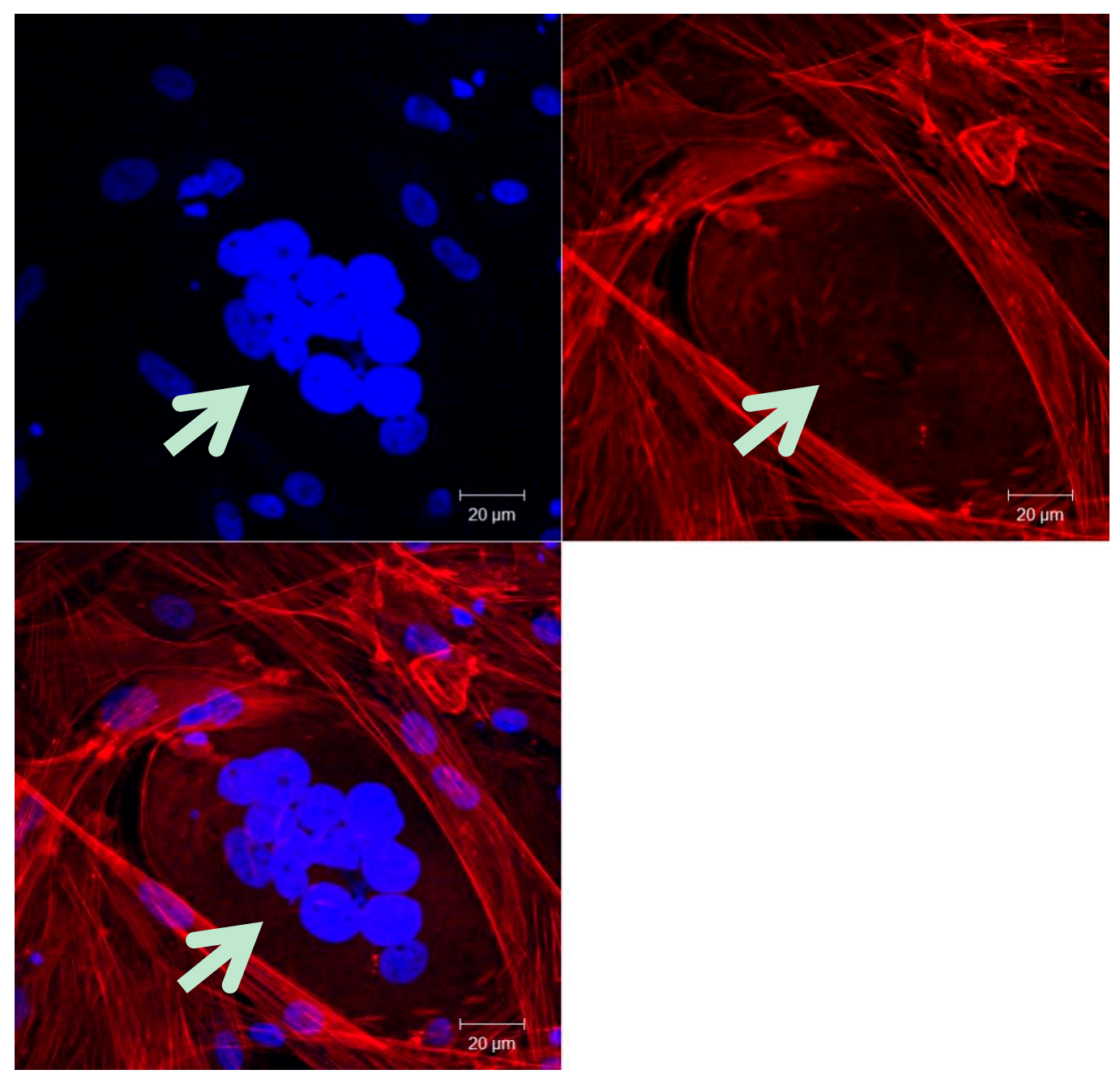

Figure 1. Multinucleated human ovarian cancer cell isolated from malignant ascites. The cells are labeled with DAPI (nucleus, blue) and Phalloidin (actin, red) and observed by confocal microscopy at magnification $400 \times$. Scale bars: $20 \mu \mathrm{m}$. The white arrow indicates the multinucleated cell.

There are four mechanisms that can lead to polyploid cells: cell fusion (as previously mentioned); endoreplication; abortive phagocytosis; and deficiencies that result in abortive cell cycles. Briefly, endoreplication occurs when DNA replication is uncoupled with cell division [12]. It is a variation of the cell cycle that generates the polyploid genome through multiple rounds of DNA replication in the absence of cellular division. One way that polyploidy is linked to cancer progression is through unscheduled endoreplication that promotes tumorigenesis by enabling chromosomal instability $[9,16]$. Endoreplication can either support or suppress tumorigenesis depending on the tissue environment and genetic background, specifically the presence of functioning p53 [9,17]. There are several defects that may lead to an abortive cell cycle, including mitotic slippage and cytokinesis failure $[10,12]$. Mitotic slippage occurs after a prolonged metaphase and the failure to satisfy the spindle assembly checkpoint. This can cause the cell to slip out of mitotic arrest and lead to a tetraploid nucleus. Cytokinesis failure can be caused from varying defects, but all result in the failure to separate the sister cells and instead form a multinucleated cell [10]. 
Cell fusion as a source of cancer progression is an idea that has been around since the early 1900s, though it lost attention until recently [3]. The hypothesis presenting that the development and progression of cancer predominantly reflects accumulation of random mutations and defects in DNA repair, associated with proliferation of progenitor cells [18] had stronger support in the scientific community, and now the hypothesis is being enlarged to include the contribution of cell fusion in cancer development and progression. Not only is there evidence of how cell fusion influences cancer progression, but as we will explain in this review, several features of cancer cells, especially metastasis, are better explained by cell fusion events contributing to the accumulation of random mutations. This new interest in cell fusion as part of cancer development has brought with it an increased number of studies trying to elucidate the mechanisms behind cell fusion. Several studies in animal and in vitro revealed that the fusion frequency in tumors was about $1 \%$ [19-22]. This data-together with the hypothesis that only $1 \%$ of the tumor hybrid cells survive, proliferate and exhibit novel properties [19]—suggests that only $0.01 \%$ of the tumor cells will be tumor hybrid cells with new properties [23]. New knowledge in the cancer field, especially concerning the tumor microenvironment, suggested that the cell fusion rate of tumor hybrid cells was likely to be higher than $0.01 \%$. Recent results demonstrated in a xenograft assay that about $6 \%$ of the tumor cells were identified as tumor hybrid cells and under certain conditions such as chemotherapy, the cell fusion rate could be increased to $12 \%$ [24]. This review will address the different stages of cell fusion, the effects of the tumor microenvironment, as well as the recent discoveries on fusogens and the mechanism likely involved in cancer cell fusion. It should be mentioned that cell fusion is a very complicated cellular process that not only comprises cell membrane fusion, but also includes several cell rearrangements and DNA metabolism, including autophagy or nucleophagy [25], though they are beyond the scope of this article. Cancer cell fusions also resemble other types of cell fusions, including events during trophoblastic development, and the genes and proteins in trophoblasts and cancer cells have many similarities, which will be as well covered in this review.

\section{Cancer Cell-Cell Fusion}

\subsection{Cancer Cell-Stromal Cell Fusion}

Cancers are influenced by both normal and malignant cells in local and distant microenvironments [26-30]. Morphological differences in tumor cells and metastases can also be attributed to interaction and fusions of cancer cells [26]. This interaction of the tumor and its surrounding stroma (endothelial, macrophages, fibroblasts) can either promote or inhibit tumor progression [26-32].

\subsubsection{Novel Hybrids}

Cell-cell fusion of tumor and stromal cells is a mechanism of genetic transfer that is involved in the progression of malignancy [26]. It has been shown in vivo that the fusion of malignant and normal cells increases malignancy in progeny in both intra- and cross-species fusions [26,32,33]. Goldenberg et al., demonstrated the transfer of seven human genes from glioblastoma cells to normal hamster host cells through heterokaryon formation [26]. Heterokaryons are cells that are formed by fusion of different types of cells [34]. These progenies were malignant and expressed in both human and hamster genes and gene products. This finding implies that cell-cell fusion is a mechanism of horizontal gene transfer and that the crosstalk of cancer cells to their stromal neighbors results in the progression of malignancy [26]. Further studies demonstrate that human genes from all human chromosomes can be transduced, transcribed, and remain functional in metastatic human hamster hybrid tumors [35].

Cell fusion is a mechanism that enables genetic material to move from one cell to another and produce viable hybrid progeny. The reciprocal genetic interchange between cancer cells and their stromal microenvironment explains the heterogeneity of cancer cells [35], which allows cancer cells to acquire distinct changes to survive and adapt to microenvironments [36]. This ability for cancer 
tumors to evolve on a cellular level is a critical process in cancer progression, and a possible target for therapy [7].

It is also possible that cell fusion can help to inhibit cancer progression when tumor suppressor genes are present in the hybrid. Tumor suppressor genes normally act in cells to prevent tumor development by inhibiting cell proliferation. In one study, hybrids of normal cells and tumor cells were not capable of forming tumors because of genes from the normal parent that inhibited the tumor progression. There are several different types of tumor suppressor genes that can be inactivated in a variety of cancers. For example, tumor suppressor gene P53 may be involved in $50 \%$ of cancers [37]. However, if a normal cell still has a functioning tumor suppressor gene, the cell fusion event could possibly inhibit the tumor progression.

\subsubsection{Metastasis}

Metastasis is arguably the deadliest component of cancer. It is responsible for nearly $90 \%$ of cancer deaths [38] because the cancer cells spread from their primary site to nearby tissues as well as distant organs [4]. One hypothesis for metastasis is the epithelial to mesenchymal transition (EMT), in which epithelial cells differentiate through biochemical changes to mesenchymal cells with phenotypes of enhanced migration and invasion, as well as resistance to apoptosis [39]. Macrophages also play an influential role in metastasis in two main ways. Tumor-associated macrophages (TAM) facilitate the metastatic cascade by preparing a pre-metastatic environment, enhancing inflammation and angiogenesis, though they are not themselves neoplastic. Macrophages also influence metastasis through cell fusion events [4,40-42].

Metastasis is being studied as a product of bone marrow-derived cell (BMDC) fusion with malignant tumor cells, where BMDC provides its capacity of migrating and the primary tumor cell supplies its proliferative capacity [43]. Many metastatic human cancers display similar molecular and behavioral characteristics of bone marrow-derived cells, including migration capabilities, secretion of growth factors, shape change, phagocytosis, fusogenicity, and antigen expression [4]. The most studied cell-cell fusion related with metastasis is the macrophage-epithelial cancer hybrids. Macrophages have two distinct activated phenotypes. M1 macrophages, activated by pro-inflammatory molecules, help initiate tumorigenesis by forming the inflamed microenvironment [4,41], while M2 macrophages, activated by anti-inflammatory molecules, promote tumor growth, angiogenesis, phagocytosis and have the ability to fuse with tumor cells $[4,44]$. A possible mechanism, that we will not address deeply in this review, of cancer hybrid cells' formation that is different from cell-cell fusion is directly linked with the phagocytosis trait of M2 macrophages. It has been suggested that macrophages, after engulfing a cell, may abort cellular digestion and result in hybrid formation [45].

After the cell-cell fusion between a BMDC and an epithelial cancer cell, the polypoid cell loses some epithelial traits such as cell-cell adhesion of E-cadherin expression, and gains mesodermal traits, mesenchymal motility mechanism, or loss of adherence, achieved by the regulation of gene expression after the cell fusion [46-48]. This process is known as epithelial-mesenchymal transition (EMT) and is very helpful for the first steps of metastasis because of the gain of motility by the tumor cells [49]. The lack of local adhesion also makes the cells more deformable, which helps the migration through the different membranes and tissues. An increase in protein level, normally expressed in macrophages that allow their motility, such as melanocortin 1 receptor (MC1R), $\beta$ 1,6 N-acetylglucosaminyltransferase $\mathrm{V}(\mathrm{GnT}-\mathrm{V})$, and secreted protein acidic and rich in cysteine (SPARC), weres observed in hybrid cells [43]. All these changes that follow the cell-cell fusion between a BMDC and an epithelial cancer cell are very helpful for metastasis, which is a complicated, multistep process characterized by the following stages: (i) Loss of adhesion to adjacent cells; (ii) Ability to traverse the basement membrane; (iii) Migration through mesodermal matrix; (iv) Intravasation into the blood or lymph circulatory system; (v) Extravasate from the vessels and (vi) Colonize distant organs or lymph nodes [50,51]. These new acquired metastatic features allow the hybrid cell to detach from the primary tumor, 
intravasate into the circulatory system, extravasate at a distant capillary bed and invade and proliferate in a distant organ where it can generate a new secondary tumor (for review, see [52]).

This cell fusion phenomenon was studied with the artificial fusion of human monocytes and mouse melanoma cells, and it was concluded that genomic DNA from parental monocyte/macrophage was integrated and the genes were expressed in the hybrids [53]. Afterward, it was proposed that tumor cells fused with host myeloid cells to create hybrids with migratory capabilities and the ability to occupy distant organs $[4,54,55]$. The fusion of macrophages (as blood-derived mesenchymal cells) and tumor epithelial in surgically joined mice demonstrated that the transcriptome identity of the progeny was similar to both the macrophage and epithelial parent cells. Additionally, there was a set of unique transcripts different from the two parents, providing evidence of how cell fusion events create metastatic cancer phenotypes [4,36].

There is also evidence of a specific macrophage marker's, CD163, expression in both breast and colorectal cancers, which is significantly related to advanced tumor stages and lower survival [56,57]. In a follow-up study it was shown that MCF-7 cancer cells obtained CD163 (and CD45) expression through hybridization of the cancer cells and macrophages, rather than in vitro paracrine cellular interaction. CD163 may also prove to be a useful cancer cell fusion biomarker in clinical contexts [57]. There is not only evidence of specific macrophage markers in hybrid cells after fusion with a macrophage, but also the hybrid cells show several macrophage traits that the tumor cells did not have prior to fusion. Phagocytosis, as previously mentioned, is a behavior of M2 macrophages that has been found in many malignant tumor cells both in vivo and in vitro. It has been reported that human cancer cells can phagocytose other tumor cells, erythrocytes, leukocytes, dead cells and other extracellular particles, conferring them a cell cannibalism property exclusive of malignant tumor cells in humans. Interestingly, cathepsins D and B, which are poor prognosis factors in cancer patients, are highly expressed by macrophages to facilitate digestion of phagocytized products, demonstrating again a higher malignancy after cell fusion (for review: [52]). Tumor cells that have macrophage properties have the potential to be the deadliest cells within a tumor [4].

Metastatic tumor cells invade distant organs in a non-random manner. The primary sites of metastasis are the lungs, liver, and bones; however, the genetic mechanism for this phenomenon is still unknown $[4,50,58]$. Paget first suggested the "seed and soil" hypothesis $[4,50,59]$ in which the tumor cells (seeds) have a preference for the distant tumors (soil) that they invade [59]. The only model of metastasis that addresses this hypothesis is metastasis as a macrophage disease, because EMT, TAM, and stem cells cannot explain this pattern of metastasis [4,60]. Macrophage presence is higher in liver and lung tissues because of the higher degree of bacterial exposure and the greater damage to resident macrophages $[4,61]$. This is a possible explanation for these sites as preferential "soil" for metastatic cancers [4]. Another example is the fusion of myeloma cells with B lymphocytes that results in metastasis in the spleen and liver $[3,62]$. Additionally, cell fusion with resident cells of the distant organ allow the survival of disseminated tumor cells in new microenvironments, which go on to progress metastases when additional oncogenes are activated [3,63]. An inflamed microenvironment is a contributor to tumor cell-macrophage cell fusions, as is radiation therapy [4,64]. The decreased survival of some irradiated cancer patients is due to the enhanced cell fusion of macrophage and epithelial cells, and specifically, it has been indicated that the human brain should never be irradiated $[60,65]$.

\subsection{Cancer Cell-Cancer Cell Fusion}

Cancer cells are highly fusogenic and can merge with other cancer cells, not limited to certain tumor types. Cancer cell fusion allows cells to quickly obtain genomic material, and changes cell genomes on a much larger scale than mutations [66]. The fusion of cancer cells can produce new acquisitions of drug resistance, multiple metastasis organotropism and clonal expansions.

Cell fusion events can contribute to cancer populations acquiring drug resistance. Some cells have the ability to resist certain drugs by activation of enzymes which can metabolize the administrated drug, by increased expression of multidrug transporters, or by lacking the drug receptor. Different cell lines 
that fuse can acquire the same resistance as the parents, and even the emergence of new drug resistance. For example, the in vitro fusion of 5-fluorouracil-resistant cells with methotrexate-resistant cells of the mammary tumor cell lines produced hybrids resistant to both drugs, creating a double-resistant cancer cell, in which elimination will be much more difficult. Interestingly, the fused cell resulting from this cancer cell-cancer cell fusion event is resistant as well to a drug that both parental cells were sensitive to, melphalan $[3,19]$. A more recent study showed that in vitro co-cultivation of hygromycin-resistant murine mammary carcinoma cells with puromycin-resistant murine BMDCs resulted in dual-resistant cells. In addition, both parental markers were found in these cells, suggesting a possible cell fusion origin, even if horizontal gene transfer cannot be rejected as a dual resistant formation hypothesis. Interestingly, the dual resistant hybrid cell showed upregulation of Abcb1a and Abcb1b multidrug transporters which conferred the cell a marked resistance towards some chemotherapeutic drugs as 17-DMAG, doxorubivin, etoposide and paclitaxel [67]. These acquisitions of new drug resistances could occur at low frequency but allows the escape of rare hybrid cells. This advantage for these hybrid cells is a source of tumor relapse [3].

In regards to the previous discussion about metastasis, it is suggested that tumor cells have the capability to occupy specific distant organs, known as metastasis organotropism [68]. In heterogeneous tumor cell populations, fusion between cancer cells can create multiple metastasis organotropisms if cells fuse with differing organ specificities. A recent study indicates that the fusion between bone-tropic and lung-tropic subpopulations results in stable hybrids with dual tropisms for both bone and lung organs [68], which express metastasis gene signatures. Multiple metastasis organotropism allows hybrids to colonize several different organs when in circulation and also to quickly re-colonize organs that have responded positively to therapies [3]. This displays another form of cell fusion, between only cancer cells, that increases metastasis and therefore the overall progression of cancer.

\subsection{Cancer Stem Cells}

Cancer stem cells (CSCs) are a rare population of cells in the tumor mass which possess the ability to initiate the growth of a heterogeneous tumor [69]. The origin of CSC remains elusive, but two potential mechanisms are described. The first one postulates that adult stem cells can accumulate genetic aberrations which will generate the CSC [70,71], and the second potential mechanism of CSC generation is through fusion between stem cells and differentiated cells [3,72-74]. The origin and rates of appearance of CSC are likely to be cancer specific, showing, for example, high frequency in melanoma, with a $25 \%$ of unselected patient-derived melanoma cells that could form xenograph tumors [75].

CSCs have the ability to initiate tumors, and they also present resistance to chemotherapy, thereby suggesting they may cause cancer relapse [76]. The characteristics conferring CSCs' resistance to chemotherapy includes the slow proliferation rate, the more efficient DNA repair mechanism, the high expression of anti-apoptotic proteins and the high-level expression of ABC multidrug pumps [76]. CSCs are also thought to have some deregulated signaling pathways that control self-renewal of normal somatic cells (such as Notch-signaling [77] and Wnt/ $\beta$-catenin signaling pathways [78]) resulting in uncontrolled self-renewal capacity of CSCs.

The origin of CSCs, as it was mentioned before, could be the cell fusion between a stem cell and a differentiated cell. Several options are observed: (i) a bone marrow stem cell and local differentiated cell; (ii) a bone marrow cell with a local stem cell; (iii) both local fusion partners with one of them being a stem cell; and (iv) a disseminated cell from a different tissue origin and a local stem cell. There is another possible scenario where a mutated cell with stem cell-like properties fuses with a differentiated cell. In all of the cases, one of the cells presents the important self-renewal capacity that the CSCs inherits [73].

CSCs are gaining interest because of their characteristics that not only confer them the ability of causing cancer relapse, but they are also hypothesized to be one of the causes of metastasis. Because of 
these different properties of CSCs, subpopulations of CSCs have been proposed. Primary CSCs (pCSCs) induce primary tumor formation and metastatic CSCs (mCSCs) induce metastases [79].

Another possible way of generating CSCs from rare cell fusion events is through polyploid giant cancer cells (PGCCs). PGCCs are large cancer cells containing multiple copies of DNA which have cancer stem-like properties [80] and are thought to generate cancer stem-like cells, contributing to cancer progression [8]. PGCCs are positive for both normal and cancer stem cell markers and have characteristics of both. For example, single PGCCs can form spheroids and generate tumors, similar to the ability of cancer stem cells [80]. Also, PGCC formation increases under multiple stressors such as antimitotic drugs, radiation, and hypoxia [80]. It is proposed that PGCCs form through cell fusion $10 \%-20 \%$ of the time and they can be three to ten times larger than normal cells. These giant cancer cells play a role in the cancer cell cycle and are highly tumorigenic and chemo-resistant [8].

\section{Mechanisms of Cell Fusion}

Cell fusion is one of the mechanisms that can lead to polyploidy, and, hence, cancer $[1-4,9,10]$. Nevertheless, polyploidy is not always a synonym of harmful consequences for the cell; on the contrary, cell fusion occurs at different levels in the organism, being essential processes for correct conception, birth and development [11].

Fecundation is the first essential cell-cell fusion event that takes places in sexual reproductive organisms. The oocyte and the spermatozoon fuse in order to mix their cellular content and generate a new living organism [81,82]. In order to develop a functional organism, several cell-cell fusion events take place [83]. In animals presenting musculature and in animals presenting skeletal system, the muscle differentiation, bone maintenance, repair and remodeling are all episodes which need the participation of cell-cell fusions [84-87]. Muscular fibers are generated by fusion of several myoblasts to form a polynucleated cell of syncytium $[84,85]$, while osteoclasts that are in charge of bone turnover are composed of several fused macrophages $[86,87]$. All these cell-cell fusion events, however, do not lead to cancer and it would be very interesting to find out the reason why polyploidy in these cases does not have an oncological fate and how the cell controls the non-tumorigenic destiny of these fused cells.

\subsection{Proteins Associated with Cell-Cell Fusion}

Cell-cell fusion events are well controlled by different proteins expressed in the fusing cells. For example, in mammalian fecundation, oocyte tetraspanins CD9 and CD81 are important for the fusing event [88-93], as well as IZUMO and A disintegrin and metalloproteinase (ADAM) sperm proteins [94-96]. For the moment, only CD9 and IZUMO have been identified as essential proteins for sperm-egg fusion, but there is no evidence indicating that these two proteins directly interact during sperm-egg fusion [5]. In myoblasts, the Ig-class of cell adhesion molecules are essential for cell-cell recognition and fusion $[97,98]$ and in osteoclasts, CD47, CD200, dendritic cell-specific transmembrane protein (DC-STAMP) and osteoclast-stimulatory transmembrane protein (OC-STAMP) seem to be important for the macrophage fusion [99-103]. DC-STAMP and OC-STAMP are the only identified transmembrane proteins essential for pre-osteoclast fusions and even though they are related, they are not interchangeable and the deficiency of one of them cannot be complemented by overexpression of the other $[104,105]$.

In addition to the tissues generated by cell-cell fusion previously mentioned, another essential tissue that mammals need in the cell-cell fusion process is the placenta [106]. Placenta development is divided in two differentiated phases. In the first stage, several cytotrophoblasts fuse together to generate polynucleated cells called syncytiotrophoblasts. These newly generated cells are highly invasive and they enter the maternal uterus. Once the syncytiotrophoblast has invaded the maternal tissue, it becomes the outer surface of the placenta, and its role changes completely. Its location confers it the ability of exchanging oxygen, nutrients and waste products between the embryo and the mother's vascular system, as well as the production of hormones and immune tolerance. 
During the performance of this second role, cytotrophoblastic cells fuse with the syncytiotrophoblast in order to renew the tissue [107-111]. During the first phase of placenta development, it was mentioned that the syncytiotrophoblastic cells are invasive cells that migrate and invade the maternal uterine decidua [107-109]; curiously, migration and invasion are also features that the cancer cells are able to perform $[3,4,112]$. Furthermore, the cell-cell fusion of cytotrophoblasts has been deeply studied and in contrast with the previously mentioned cell-cell events, essential bona fide fusogens have been found in the syncytiotrophoblast fusion formation event $[113,114]$. These fusogens are class I envelope (env) human endogenous retroviruses (HERV) that were acquired in humans from retroviruses [113-115] and act similarly to target-soluble $N$-ethylmaleimide-sensitive factor attachment protein receptor (t-SNARE) and vesicular-SNARE (v-SNARE) [116]. These two proteins mediate the fusion of intracellular membranes by forming bundles of alpha-helixes, which result in membrane apposition and fusion $[116,117]$. Interestingly, engineered flipping of t-SNARE and v-SNARE into the surface of cell membranes has been shown to promote cell-cell fusion [116,118,119]. Two identified cell-cell fusogens that appear to use a similar $\alpha$-helixes fusion mechanism are syncytin 1 (acquired 19-28 million years ago) [113,114,120] and syncytin 2 (acquired 40 million years ago) [115] and are part of the $8 \%$ of the human genome that were acquired from retroviruses [121]. Interestingly, in addition to the similar features between syncytiotrophoblast and cancer cells (migration and invasion), several studies have found a high expression of syncytin 1, syncytin 2 and their receptors in different cancers, supporting an important function of this envelope human endogenous retrovirus (env HERV) proteins in cancer progression [122-131] (Table 1). Different human breast cancer cell lines and 38\% of the breast cancer specimens studied expressed syncytin [129]. The alanine, serine and cysteine selective transporter 2 (ASCT2) receptor of syncytin 1 was furthermore expressed in endothelial and cancer cells [130,132-135], allowing a demonstrated fusion between breast cancer cells and endothelial cells that can be inhibited by syncytin inhibitory peptides [130]. Additionally, in endometrial carcinoma tissues, syncytin 1 is upregulated in both malignant and benign tumors, as well as ASCT1 and ASCT2 expression. But these are not the only types of cancers that have been reported to overexpress envelope HERV proteins or have their receptors in cells where basal expression is lower. There is even expression of envelope HERV protein in cell types where its expression is normally absent. The different cell lines that were found to express syncytin 1 are summarized in Table 1; even though they have not been demonstrated to fuse in the different cancer tissues, they probably have the ability to fuse with other cells expressing syncytin 1 receptors. The reason why these envelope HERV proteins are overexpressed or expressed is not completely clear, but a hypothesis suggests that the abnormal number of chromosomes or mutations in cancer cells change the protein expression pattern, affecting the expression of these envelope HERV proteins and their receptors [135].

Moreover, other proteins have been identified as playing an important role in the syncytialization process. E-Cadherin, cadherin-11, zona ocludens-1 (ZO-1), connexin-43 and $78 \mathrm{kDa}$ glucose-regulated protein (GRP78) are some of these proteins involved in the cell-cell fusion process [107,136-138]. GRP78, a reticulum endoplasmic protein, has been found in the surface of trophoblastic cells where it plays a role in cell fusion. Interestingly, cancer cells also express this protein at their surface, probably displaying a function in cancer cell fusion [136]. 
Table 1. Expression of syncytin in different human cancers.

\begin{tabular}{ccc}
\hline Protein & Human Tissue or Cell Line & References \\
\hline Syncytin 1 & Cutaneous T-cell lymphoma & {$[122]$} \\
Syncytin 1 & Urothelial cell carcinoma & {$[123]$} \\
Syncytin 1 & Endometrial carcinoma & {$[124,125]$} \\
Syncytin 1 & Leukemia cells & {$[126,127]$} \\
Syncytin 1 & Lymphoma cells & {$[126,127]$} \\
Syncytin 1 & Colorectal carcinoma & {$[128]$} \\
Syncytin 1 & Breast cancer & {$[127,129,130]$} \\
Syncytin 1 & Ovarian carcinoma cell line & {$[127,131]$} \\
Syncytin 1 & Gastric cell line & {$[127,131]$} \\
Syncytin 1 & Lung carcinoma cell line & {$[127,131]$} \\
\hline & Brain carcinoma cell line & \\
& Cervix carcinoma cell line & \\
& Melanoma cell line & \\
& Prostate cancer cell line & \\
Syncytin 1 & Pancreatic carcinoma cell line & {$[127]$} \\
& Hepatocellular carcinoma cell line & \\
& Kidney carcinoma cell line & \\
& Squamous carcinoma cell line & \\
& Colon carcinoma cell line & \\
\hline Syncytin 2 & Bladder carcinoma cell line \\
\hline
\end{tabular}

\subsection{Syncytin-Dependent Fusion Mechanism}

Syncytin 1 (HERV-W) and syncytin 2 (HERV-FDR) are envelope human endogenous retrovirus proteins characterized by binding to the receptor and achieving the membrane fusion in a $\mathrm{pH}$-independent manner [106,107]. The sophisticated mechanism that class I envelope proteins use to fuse the membranes is well defined in viruses, and the high homology of the envelope HERV with the retroviral envelope proteins implies the use of the same or very similar mechanism of fusion $[106,107,139,140]$. Cell fusion in cancer is poorly understood, but certain steps and cellular components can be surmised from the fusion events already understood.

Syncytin-1-dependent fusion mechanism has been better characterized than syncytin-2-dependent fusion mechanism, so we will focus on the first one. Syncytin-1, like all the retroviral envelope proteins, is a glycoprotein composed of a surface unit (SU) and a transmembrane unit (TM). The SU contains a receptor binding domain (RBD), a furin cleavage site $\left({ }^{314-} \mathrm{RNKR}^{-317}\right), 6 \mathrm{~N}$-glycosylation sites and a $\mathrm{C}_{\Phi \Phi} \mathrm{C}\left({ }^{186-} \mathrm{CX}_{2} \mathrm{C}^{-189}\right)$ motif. On the other hand, TM contains a fusion peptide (FP), two heptad repeats (HR1 and HR2), a transmembrane anchorage domain (tm), a cytosolic tail (cyt), $1 \mathrm{~N}$-glycosylation site and a ${ }^{397-}{ }^{-} x_{6} C^{-407}$ domain. SU and TM are translated together, but $\mathrm{SU}$ contains a furin cleavage site, a conserved cleavage site that can be cleaved by proteases like furin-convertase enzyme separating both units (Figure 2A). The protein is translated and folded in the endoplasmic reticulum, where the cleavage of both subunits is done prior to a disulfide bond formation between the ${ }^{397-} \mathrm{Cx}_{6} \mathrm{C}^{-407}$ domain of TM and ${ }^{186-} \mathrm{CX}_{2} \mathrm{C}^{-189}$ motif of SU $[106,107,139,140]$. Functional syncytin 1 is a trimer, in which trimerization takes place in the endoplasmic reticulum. After maturation in Golgi apparatus, the mature functional protein is transported to the membrane where it can trigger cell-cell fusion [106].

In order for cell-cell fusion to take place, syncytin 1 has to recognize a receptor in the target membrane, which in the case of this protein can be either ASCT1 or ASCT2. The receptor binding domain located in the SU subunit of syncytin 1 recognizes its particular receptor located in the target membrane and a conformational change in the trimer produces the dissociation of the SU subunit and the TM subunit by breakage of the disulfide bond. This structure modification generates a loop-to-helix movement of the syncytin 1 fusion peptide causing its projection toward the top of the glycoprotein, interacting with the target membrane and strongly inserting into it [106,107]. Once both membranes 
are firmly connected through the envelope protein, the HR2 domain folds back and interacts with the HR1 domain, reversing the direction of the cell membrane and bringing both membranes in close proximity [106] (Figure 2B). The proximity of the membranes considerably reduces the free energy needed to overcome the barrier to merge $[106,107]$.

A
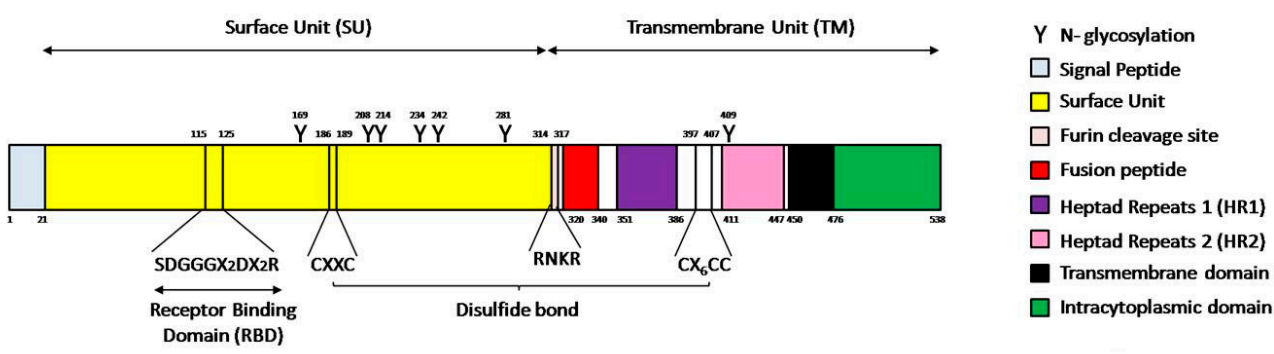

\section{B}

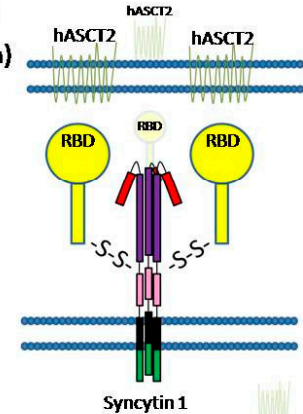

b)

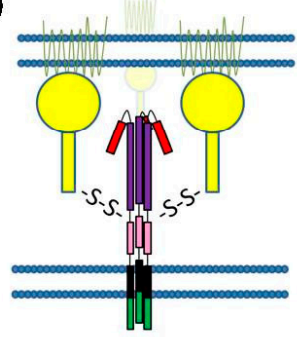

c)

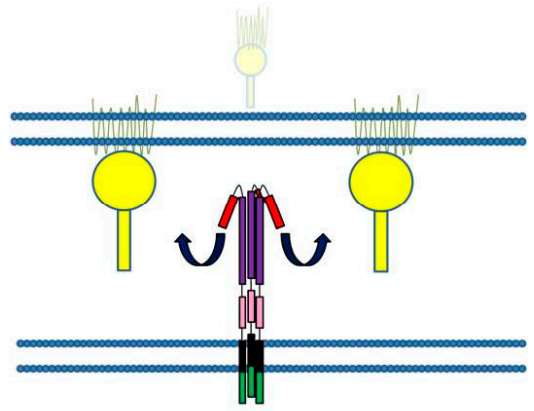

d)

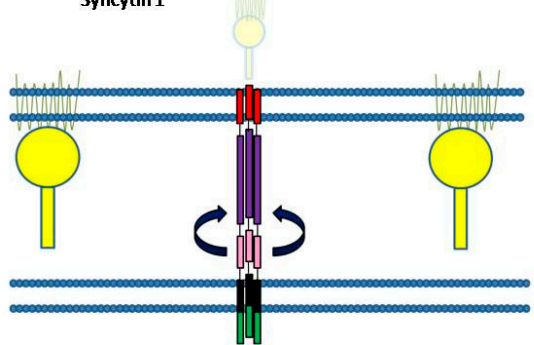

e)

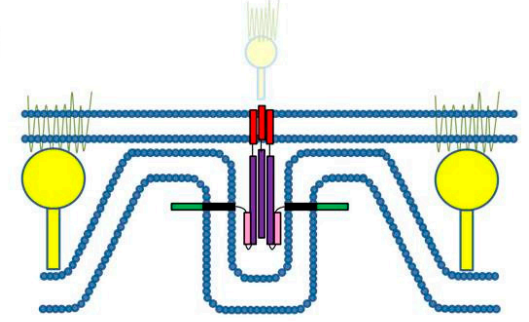

Figure 2. Cell fusion mediated by syncytin 1. (A) Schematic portrait of syncytin 1 structure. The signal peptide domain is represented in light blue. The surface unit (SU) is represented in yellow and contains a receptor binding domain (RBD; SDGGGX2DX2R) and a CXXC motif. The transmembrane unit (TM) contains a fusion peptide represented in red, heptad repeats 1 (HR1) represented in purple, heptad repeats 2 (HR2) represented in pink, a transmembrane domain represented in black, an intracytoplasmic domain represented in green and a CX6CC domain. Between the SU and the TM is a furin cleavage site (RNKR) represented in light red. The $\mathrm{Y}$ indicate $\mathrm{N}$-glycosylation sites and numbers indicate the amino acid position. A disulfide bond is formed between the CXXC motif of SU and the CX6CC domain of TM; (B) Schematic representation of syncytin 1-dependent cell fusion. (a) Resting stage; (b) RBD (yellow) binding to the hASCT2 receptor (light green); (c) Disulfide bond breaking and removing of SU domains, producing a conformational change in syncytin 1 protein leading to the insertion of the fusion peptide (red) into the cell membrane; (d) Assembly of HR2 (pink) and HR1 (purple); (e) Final stage with the membranes in close proximity and initiation of membrane bending. Adapted from [106,107].

\subsection{Model of Membrane Fusion}

The first membrane-merging step consists of a hemifusion where only the outer leaflets of both membranes are fused. The close proximity of the membranes and the contact of the opposing outer cell membranes causes dehydration of the contact site, reducing the hydration repulsion between the outer leaflets of the membranes. This reduction of repulsion leads to the formation of a fusion stalk, where only the outer leaflets of the membranes are fused $[106,107,141]$. Nevertheless, the close proximity of cell membranes and dehydration are not enough for the hemifusion to take place. 
The localization of negatively charged phospholipids as phosphatidylserine in the outer membrane has been shown to be required for syncytial fusion as well as for skeletal muscle formation and, interestingly, trophoblast-derived BeWo choriocarcinoma cell line fusion. This redistribution of phosphatidylserine from its normal location in the inner leaflet to the abnormal location in the outer membrane is called phosphatidylserine flip $[106,107,141-144]$. After the formation of a fusion stalk facilitated by all of these different events, radial expansion of the fusion stalk occurs, and it ends up in the appearance of a hemifusion diagram where the inner leaflets are still separated. Finally, the inner leaflets fuse as well, causing a complete merge of the membranes and the opening of a pore by which the cell content can mix, finally achieving the cell-cell fusion [106].

\section{Discussion}

Cell-cell fusion is a necessary activity which needs to be controlled in order to perform correctly, or medical conditions may result. The importance of cell-cell fusion spans from viral survival, to fecundation of gametes, to the correct development of the embryo and the adult [81-87]. Wrong cell-cell fusion in trophoblast can generate difficulties in the pregnancy, both for the embryo and the mother, such as preeclampsia [145-147]. While wrong cell-cell fusion of osteoclasts generates bone turnover problems, including osteoporosis [148], wrong cell-cell myoblast fusion generates malformation of the muscles $[84,85]$. All of these events are very complicated and their control should be strictly supervised.

Recent studies have revealed some of the effectors that are implicated in the control of cell-cell fusion, but the spotlight is centered on uncovering the proteins implicated in the direct fusion: the fusogens. The investigations are going in the right direction with new effectors appearing continuously, but the identification of bonafide fusogens is still not achieved. Great advances have been made in the identification of fusogens and adjuvant proteins implicated in cell-cell fusion during fecundation, with CD9 and IZUMO as promising proteins [88-91,96]. In other cell-cell fusion, such as those in muscle fibers or bone, identification is taking longer, even with the understanding of these cell-cell fusions [97-103]. The only bonafide fusogen that has been found is the one implicated in the syncytiotrophoblast fusion, syncytin 1 . This envelope HERV protein has been found to drive the direct interaction between membranes, bringing them together and making them fuse $[113,114,120]$.

It is interesting how this envelope HERV protein, together with other env HERV proteins in the human genome, can generate the fusion of cells for something as important as placenta formation, and how, at the same time, it can be used by other cells to generate cancer or metastasis [125,127-131].

The lack of control in the expression of env HERV proteins and their receptors can lead to cell-cell fusion that will generate aneuploidy cells that will in the end generate cancer tumor cells. It is surprising how an uncontrolled expression of a few proteins that are necessary for correct development, can be used by cancer cells to induce tumor development and metastasis [125,127-135].

Cell-cell fusion is not only implicated in the generation of cancer cells but also in the progression of cancer. Cancer cell fusion with other cells in the body, such as BMDC, can lead to metastasis and increased malignancy $[43,49,51]$. The cell fusion of tumorigenic cells and BMDC leads to metastasis through the combination of the activities of each of the mixing cells. The tumorigenic cell supplies the proliferation activity while the BMDC supplies the migration and invasion activity [43]. These cell-cell fusions are very convenient for the cancer tumors as they are able to assure their survival in the body by colonizing new organs $[4,44]$.

Even though virus-cell fusion mechanisms are already well defined, and cell-cell fusion mechanisms are only partially understood, very little about fusion mechanisms in cancer cells has been described. Nevertheless, all the different proteins implicated both in cancer cell fusion and in physiological cell fusion leads us to recognize high resemblance between the fusion mechanisms used by physiological cells, especially syncytiotrophoblast, and cancer cells [125,127-131]. For the moment, investigations trying to elude the cancer cell fusion mechanisms are not very advanced, but the alikeness of the two processes permit us to use the placenta trophoblast fusion as a basis for cancer cell 
fusion investigation. The study of the cancer cell fusion mechanisms could be interesting for a better general understanding of cancer, as well as a potential treatment against the disease.

Although surgery and chemotherapy treatments against cancer cells are reducing the mortality of this disease, we are still far from having a thorough understanding of the disease and finding a way to eradicate it. Chemotherapy treatments against cancer cells are very useful in reducing the tumor size or completely eliminating it by attacking the cancer cells directly [149]. However, resistance to drugs is a feature that some of the cancer cells have and, at least in vitro, probably through cell fusion, double-resistant cells can be generated leading to a more complicated cell to eliminate $[3,19,67]$.

Until now we have commented on how cell-cell fusion has turned against us by generating hybrid cells that can lead to one of the most lethal diseases, from something that is completely necessary for our development. Recent studies are trying to elucidate a way to turn cell-cell fusion to our benefit by counterattacking the cancer cells with artificially created fused cells [150,151].

The cell-cell fusion events happening in our body to generate cancer cells cannot be predicted and thus, we cannot anticipate stopping them from happening. But we can attack them once the fused cancer cells have already been originated. Dendritic cells (DC) are the most potent antigen-presenting cells and are able to initiate primary immune response [152,153]. If tumor cell antigens are loaded into DC, these DC will induce antitumor immunity and induce tumor regression after recognition of the antibodies expressed by tumor cells [150]. In order to have DC expressing the tumor cell antigens, a cell-cell fusion strategy can be used. By fusing these two types of cells with polyethylene glycol [151,154], electrofusion [155-157] or virus-mediated fusion [158,159], DC will process and present the tumor antigens, allowing the body to be prepared to recognize and attack the tumor cells $[150,151,154-159]$.

There are still a lot of questions to answer about how cell-cell fusion is induced to generate polyploid cancer cells, how it takes place and, especially, how to stop it. Although the results recently obtained are promising and help us better understand the process, there is still a long way to go before completely understanding it, especially since cell-cell fusion occurs at all tissue levels and all cell types, so no generalities can be concluded. Regardless, little by little, more questions will find their answers and the puzzle will be finally solved.

Acknowledgments: We would like to thank the Swiss National Science Foundation (31003A_163395 grant) and the Fondation pour la lutte contre le cancer for their economical support, and Pascale Ribaux for her technical assistance.

Author Contributions: Daniel Bastida-Ruiz and Kylie Van Hoesen wrote the paper. Marie Cohen discussed and corrected the paper.

Conflicts of Interest: The authors declare no conflict of interest.

\section{Abbreviations}

$\begin{array}{ll}\text { Abcb1a } & \text { ATP-binding cassette b1a multidrug transporter. } \\ \text { Abcb1b } & \text { ATP-binding cassette b1b multidrug transporter. } \\ \text { ADAM } & \text { A disintegrin and metalloproteinase } \\ \text { ASCT1 } & \text { Alanine, Serine and Cysteine selective transporter 1 } \\ \text { ASCT2 } & \text { Alanine, serine and cysteine selective transporter } 2 \\ \text { BMDCs } & \text { Bone marrow-derived cells } \\ \text { CD } & \text { Cluster of Differentiation } \\ \text { CSCs } & \text { Cancer stem cells } \\ \text { Cyt } & \text { Cytosolic tail } \\ \text { DC } & \text { Dendritic cells } \\ \text { DC-STAMP } & \text { Dendritic cell-specific transmembrane protein } \\ \text { DNA } & \text { Deoxyribonucleic acid } \\ \text { EMT } & \text { Epithelial to mesenchymal transition }\end{array}$




$\begin{array}{ll}\text { Env } & \text { Envelope } \\ \text { FP } & \text { Fusion peptide } \\ \text { GnT-V } & \beta 1,6 \text {-acetylglucosaminyltransferase V } \\ \text { GRP78 } & 78 \text { kDa glucose-regulated protein } \\ \text { HERV } & \text { Human endogenous retrovirus } \\ \text { HR1 } & \text { Heptad repeats } \\ \text { HR2 } & \text { Heptad repeats } \\ \text { LD } & \text { Linear dichroism } \\ \text { MC1R } & \text { Melanocortin 1 receptor } \\ \text { mCSCs } & \text { metastatic cancer stem cells } \\ \text { OC-STAMP } & \text { Osteoclast-stimulatory transmembrane protein } \\ \text { pCSCs } & \text { Primary cancer stem cells } \\ \text { PGCCs } & \text { Polyploid giant cancer cells } \\ \text { RBD } & \text { Receptor binding domain } \\ \text { SPARC } & \text { Secreted protein acidic and rich in cysteine } \\ \text { SU } & \text { Surface unit } \\ \text { t-SNARE } & \text { target-soluble } N \text {-ethylmaleimide-sensitive factor attachment protein receptor } \\ \text { TAM } & \text { Tumor-associated macrophages } \\ \text { TM } & \text { Transmembrane unit } \\ \text { Tm } & \text { Transmembrane anchorage domain } \\ \text { v-SNARE } & \text { vesicular-soluble } N \text {-ethylmaleimide-sensitive factor attachment protein receptor } \\ \text { ZO-1 } & \text { Zona ocludens- } 1\end{array}$

\section{References}

1. Yokota, J. Tumor progression and metastasis. Carcinogenesis 2000, 21, 497-503. [CrossRef] [PubMed]

2. Rajagopalan, H.; Nowak, M.A.; Vogelstein, B.; Lengauer, C. The significance of unstable chromosomes in colorectal cancer. Nat. Rev. Cancer 2003, 3, 695-701. [CrossRef] [PubMed]

3. Lu, X.; Kang, Y. Cell fusion as a hidden force in tumor progression. Cancer Res. 2009, 69, 8536-8539. [CrossRef] [PubMed]

4. Seyfried, T.N.; Huysentruyt, L.C. On the origin of cancer metastasis. Crit. Rev. Oncog. 2013, 18, 43-73. [CrossRef] [PubMed]

5. Aguilar, P.S.; Baylies, M.K.; Fleissner, A.; Helming, L.; Inoue, N.; Podbilewicz, B.; Wang, H.; Wong, M. Genetic basis of cell-cell fusion mechanisms. Trends Genet. 2013, 29, 427-437. [CrossRef] [PubMed]

6. Mohr, M.; Zanker, K.S.; Dittmar, T. Cancer (stem) cell differentiation: An inherent or acquired property? Med. Hypotheses 2015, 85, 1012-1018. [CrossRef] [PubMed]

7. Coward, J.; Harding, A. Size does matter: Why polyploid tumor cells are critical drug targets in the war on cancer. Front. Oncol. 2014, 4, 123. [CrossRef] [PubMed]

8. Zhang, S.; Mercado-Uribe, I.; Xing, Z.; Sun, B.; Kuang, J.; Liu, J. Generation of cancer stem-like cells through the formation of polyploid giant cancer cells. Oncogene 2014, 33, 116-128. [CrossRef] [PubMed]

9. Fox, D.T.; Duronio, R.J. Endoreplication and polyploidy: Insights into development and disease. Development 2013, 140, 3-12. [CrossRef] [PubMed]

10. Gentric, G.; Desdouets, C. Polyploidization in liver tissue. Am. J. Pathol. 2014, 184, 322-331. [CrossRef] [PubMed]

11. Davoli, T.; de Lange, T. The causes and consequences of polyploidy in normal development and cancer. Annu. Rev. Cell Dev. Biol. 2011, 27, 585-610. [CrossRef] [PubMed]

12. Storchova, Z.; Pellman, D. From polyploidy to aneuploidy, genome instability and cancer. Nat. Rev. Mol. Cell Biol. 2004, 5, 45-54. [CrossRef] [PubMed]

13. Ganem, N.J.; Storchova, Z.; Pellman, D. Tetraploidy, aneuploidy and cancer. Curr. Opin. Genet. Dev. 2007, 17, 157-162. [CrossRef] [PubMed] 
14. Storchova, Z.; Kuffer, C. The consequences of tetraploidy and aneuploidy. J. Cell Sci. 2008, 121, 3859-3866. [CrossRef] [PubMed]

15. Dewhurst, S.M.; McGranahan, N.; Burrell, R.A.; Rowan, A.J.; Gronroos, E.; Endesfelder, D.; Joshi, T.; Mouradov, D.; Gibbs, P.; Ward, R.L.; et al. Tolerance of whole-genome doubling propagates chromosomal instability and accelerates cancer genome evolution. Cancer Discov. 2014, 4, 175-185. [CrossRef] [PubMed]

16. Ganem, N.J.; Pellman, D. Limiting the proliferation of polyploid cells. Cell 2007, 131, 437-440. [CrossRef] [PubMed]

17. McClendon, A.K.; Dean, J.L.; Ertel, A.; Fu, Z.; Rivadeneira, D.B.; Reed, C.A.; Bourgo, R.J.; Witkiewicz, A.; Addya, S.; Mayhew, C.N.; et al. Rb and p53 cooperate to prevent liver tumorigenesis in response to tissue damage. Gastroenterology 2011, 141, 1439-1450. [CrossRef] [PubMed]

18. Martincorena, I.; Campbell, P.J. Somatic mutation in cancer and normal cells. Science 2015, 349, $1483-1489$. [CrossRef] [PubMed]

19. Duelli, D.; Lazebnik, Y. Cell fusion: A hidden enemy? Cancer Cell 2003, 3, 445-448. [CrossRef]

20. Wakeling, W.F.; Greetham, J.; Bennett, D.C. Efficient spontaneous fusion between some co-cultured cells, especially murine melanoma cells. Cell Biol. Int. 1994, 18, 207-210. [CrossRef] [PubMed]

21. Fortuna, M.B.; Dewey, M.J.; Furmanski, P. Cell fusion in tumor development and progression: Occurrence of cell fusion in primary methylcholanthrene-induced tumorigenesis. Int. J. Cancer 1989, 44, 731-737. [CrossRef] [PubMed]

22. Miller, F.R.; McInerney, D.; Rogers, C.; Miller, B.E. Spontaneous fusion between metastatic mammary tumor subpopulations. J. Cell. Biochem. 1988, 36, 129-136. [CrossRef] [PubMed]

23. Dittmar, T.; Zanker, K.S. Tissue regeneration in the chronically inflamed tumor environment: Implications for cell fusion driven tumor progression and therapy resistant tumor hybrid cells. Int. J. Mol. Sci. 2015, 16, 30362-30381. [CrossRef] [PubMed]

24. Yan, B.; Wang, J.; Liu, L. Chemotherapy promotes tumour cell hybridization in vivo. Tumour Biol. 2016, 37, 5025-5030. [CrossRef] [PubMed]

25. Clawson, G.A.; Matters, G.L.; Xin, P.; Imamura-Kawasawa, Y.; Du, Z.; Thiboutot, D.M.; Helm, K.F.; Neves, R.I.; Abraham, T. Macrophage-tumor cell fusions from peripheral blood of melanoma patients. PLoS ONE 2015, 10, e0134320.

26. Goldenberg, D.M.; Zagzag, D.; Heselmeyer-Haddad, K.M.; Berroa Garcia, L.Y.; Ried, T.; Loo, M.; Chang, C.H.; Gold, D.V. Horizontal transmission and retention of malignancy, as well as functional human genes, after spontaneous fusion of human glioblastoma and hamster host cells in vivo. Int. J. Cancer 2012, 131, 49-58. [CrossRef] [PubMed]

27. Tlsty, T.D. Stromal cells can contribute oncogenic signals. Semin. Cancer Biol. 2001, 11, 97-104. [CrossRef] [PubMed]

28. Mueller, M.M.; Fusenig, N.E. Friends or foes-Bipolar effects of the tumour stroma in cancer. Nat. Rev. Cancer 2004, 4, 839-849. [CrossRef] [PubMed]

29. Proia, D.A.; Kuperwasser, C. Stroma: Tumor agonist or antagonist. Cell Cycle 2005, 4, 1022-1025. [CrossRef] [PubMed]

30. Joyce, J.A.; Pollard, J.W. Microenvironmental regulation of metastasis. Nat. Rev. Cancer 2009, 9, $239-252$. [CrossRef] [PubMed]

31. Chakraborty, A.K.; Sodi, S.; Rachkovsky, M.; Kolesnikova, N.; Platt, J.T.; Bolognia, J.L.; Pawelek, J.M. A spontaneous murine melanoma lung metastasis comprised of host $x$ tumor hybrids. Cancer Res. 2000, 60, 2512-2519. [PubMed]

32. Miller, F.R.; Mohamed, A.N.; McEachern, D. Production of a more aggressive tumor cell variant by spontaneous fusion of two mouse tumor subpopulations. Cancer Res. 1989, 49, 4316-4321. [PubMed]

33. Jacobsen, B.M.; Harrell, J.C.; Jedlicka, P.; Borges, V.F.; Varella-Garcia, M.; Horwitz, K.B. Spontaneous fusion with, and transformation of mouse stroma by, malignant human breast cancer epithelium. Cancer Res. 2006, 66, 8274-8279. [CrossRef] [PubMed]

34. Ogle, B.M.; Cascalho, M.; Platt, J.L. Biological implications of cell fusion. Nat. Rev. Mol. Cell Biol. 2005, 6, 567-575. [CrossRef] [PubMed]

35. Goldenberg, D.M.; Rooney, R.J.; Loo, M.; Liu, D.; Chang, C.H. In-vivo fusion of human cancer and hamster stromal cells permanently transduces and transcribes human DNA. PLoS ONE 2014, 9, e107927. [CrossRef] [PubMed] 
36. Powell, A.E.; Anderson, E.C.; Davies, P.S.; Silk, A.D.; Pelz, C.; Impey, S.; Wong, M.H. Fusion between intestinal epithelial cells and macrophages in a cancer context results in nuclear reprogramming. Cancer Res. 2011, 71, 1497-1505. [CrossRef] [PubMed]

37. Cooper, G.M. Tumor suppressor genes. In The Cell: A Molecular Approach, 2nd ed.; Sinauer Associates: Sunderland, MA, USA, 2000.

38. Chaffer, C.L.; Weinberg, R.A. A perspective on cancer cell metastasis. Science 2011, 331, 1559-1564. [CrossRef] [PubMed]

39. Kalluri, R.; Neilson, E.G. Epithelial-mesenchymal transition and its implications for fibrosis. J. Clin. Investig. 2003, 112, 1776-1784. [CrossRef] [PubMed]

40. Qian, B.Z.; Pollard, J.W. Macrophage diversity enhances tumor progression and metastasis. Cell 2010, 141, 39-51. [CrossRef] [PubMed]

41. Hanahan, D.; Coussens, L.M. Accessories to the crime: Functions of cells recruited to the tumor microenvironment. Cancer Cell 2012, 21, 309-322. [CrossRef] [PubMed]

42. Peinado, H.; Rafii, S.; Lyden, D. Inflammation joins the "Niche". Cancer Cell 2008, 14, 347-349. [CrossRef] [PubMed]

43. Pawelek, J.M.; Chakraborty, A.K. Fusion of tumour cells with bone marrow-derived cells: A unifying explanation for metastasis. Nat. Rev. Cancer 2008, 8, 377-386. [CrossRef] [PubMed]

44. Biswas, S.K.; Sica, A.; Lewis, C.E. Plasticity of macrophage function during tumor progression: Regulation by distinct molecular mechanisms. J. Immunol. 2008, 180, 2011-2017. [CrossRef] [PubMed]

45. Pawelek, J.M. Tumour cell hybridization and metastasis revisited. Melanoma Res. 2000, 10, 507-514. [CrossRef] [PubMed]

46. Friedl, P. Prespecification and plasticity: Shifting mechanisms of cell migration. Curr. Opin. Cell Biol. 2004, 16, 14-23. [CrossRef] [PubMed]

47. Kang, Y.; Massague, J. Epithelial-mesenchymal transitions: Twist in development and metastasis. Cell 2004, 118, 277-279. [CrossRef] [PubMed]

48. Thiery, J.P.; Acloque, H.; Huang, R.Y.; Nieto, M.A. Epithelial-mesenchymal transitions in development and disease. Cell 2009, 139, 871-890. [CrossRef] [PubMed]

49. Yang, J.; Mani, S.A.; Donaher, J.L.; Ramaswamy, S.; Itzykson, R.A.; Come, C.; Savagner, P.; Gitelman, I.; Richardson, A.; Weinberg, R.A. Twist, a master regulator of morphogenesis, plays an essential role in tumor metastasis. Cell 2004, 117, 927-939. [CrossRef] [PubMed]

50. Fidler, I.J. The pathogenesis of cancer metastasis: The "seed and soil" hypothesis revisited. Nat. Rev. Cancer 2003, 3, 453-458. [CrossRef] [PubMed]

51. Thiery, J.P. Epithelial-mesenchymal transitions in tumour progression. Nat. Rev. Cancer 2002, 2, $442-454$. [CrossRef] [PubMed]

52. Huysentruyt, L.C.; Seyfried, T.N. Perspectives on the mesenchymal origin of metastatic cancer. Cancer Metastasis Rev. 2010, 29, 695-707. [CrossRef] [PubMed]

53. Chakraborty, A.K.; de Freitas Sousa, J.; Espreafico, E.M.; Pawelek, J.M. Human monocyte x mouse melanoma fusion hybrids express human gene. Gene 2001, 275, 103-106. [CrossRef]

54. Mekler, L.B.; Drize, O.B.; Osechinskii, I.V.; Shliankevich, M.A. Transformation of a normal differentiated cell of an adult organism, induced by the fusion of this cell with another normal cell of the same organism but with different organ or tissue specificity. Vestn. Akad. Med. Nauk. SSSR 1971, 26, 75-80. [PubMed]

55. Warner, T.F. Cell hybridizaiton: An explanation for the phenotypic diversity of certain tumours. Med. Hypotheses 1975, 1, 51-57. [CrossRef]

56. Shabo, I.; Olsson, H.; Sun, X.F.; Svanvik, J. Expression of the macrophage antigen CD163 in rectal cancer cells is associated with early local recurrence and reduced survival time. Int. J. Cancer 2009, 125, 1826-1831. [CrossRef] [PubMed]

57. Shabo, I.; Midtbo, K.; Andersson, H.; Akerlund, E.; Olsson, H.; Wegman, P.; Gunnarsson, C.; Lindstrom, A. Macrophage traits in cancer cells are induced by macrophage-cancer cell fusion and cannot be explained by cellular interaction. BMC Cancer 2015, 15, 922. [PubMed]

58. Chambers, A.F.; Groom, A.C.; MacDonald, I.C. Dissemination and growth of cancer cells in metastatic sites. Nat. Rev. Cancer 2002, 2, 563-572. [CrossRef] [PubMed]

59. Paget, S. The distribution of secondary growths in cancer of the breast. 1889. Cancer Metastasis Rev. 1989, 8 , 98-101. [PubMed] 
60. Seyfried, T. Cancer as a Metabolic Disease: On the Origin, Management, and Prevention of Cancer, 1st ed.; John Wiley \& Sons: Hoboken, NJ, USA, 2012.

61. Hofer, S.O.; Molema, G.; Hermens, R.A.; Wanebo, H.J.; Reichner, J.S.; Hoekstra, H.J. The effect of surgical wounding on tumour development. Eur. J. Surg. Oncol. 1999, 25, 231-243. [CrossRef] [PubMed]

62. De Baetselier, P.; Roos, E.; Brys, L.; Remels, L.; Gobert, M.; Dekegel, D.; Segal, S.; Feldman, M. Nonmetastatic tumor cells acquire metastatic properties following somatic hybridization with normal cells. Cancer Metastasis Rev. 1984, 3, 5-24. [CrossRef] [PubMed]

63. Podsypanina, K.; Du, Y.C.; Jechlinger, M.; Beverly, L.J.; Hambardzumyan, D.; Varmus, H. Seeding and propagation of untransformed mouse mammary cells in the lung. Science 2008, 321, 1841-1844. [CrossRef] [PubMed]

64. Levin, T.G.; Powell, A.E.; Davies, P.S.; Silk, A.D.; Dismuke, A.D.; Anderson, E.C.; Swain, J.R.; Wong, M.H. Characterization of the intestinal cancer stem cell marker CD166 in the human and mouse gastrointestinal tract. Gastroenterology 2010, 139, 2072-2082. [CrossRef] [PubMed]

65. Seyfried, T.N.; Kiebish, M.A.; Marsh, J.; Shelton, L.M.; Huysentruyt, L.C.; Mukherjee, P. Metabolic management of brain cancer. Biochim. Biophys. Acta 2011, 1807, 577-594. [CrossRef] [PubMed]

66. Zhang, J.; Lou, X.; Zellmer, L.; Liu, S.; Xu, N.; Liao, D.J. Just like the rest of evolution in mother nature, the evolution of cancers may be driven by natural selection, and not by haphazard mutations. Oncoscience 2014, 1, 580-590. [CrossRef] [PubMed]

67. Nagler, C.; Hardt, C.; Zanker, K.S.; Dittmar, T. Co-cultivation of murine bmdcs with 67NR mouse mammary carcinoma cells give rise to highly drug resistant cells. Cancer Cell Int. 2011, 11, 21. [CrossRef] [PubMed]

68. Lu, X.; Kang, Y. Efficient acquisition of dual metastasis organotropism to bone and lung through stable spontaneous fusion between MDA-MB-231 variants. Proc. Natl. Acad. Sci. USA 2009, 106, 9385-9390. [CrossRef] [PubMed]

69. Clarke, M.F.; Dick, J.E.; Dirks, P.B.; Eaves, C.J.; Jamieson, C.H.; Jones, D.L.; Visvader, J.; Weissman, I.L.; Wahl, G.M. Cancer stem cells-perspectives on current status and future directions: AACR workshop on cancer stem cells. Cancer Res. 2006, 66, 9339-9344. [CrossRef] [PubMed]

70. Bjerkvig, R.; Tysnes, B.B.; Aboody, K.S.; Najbauer, J.; Terzis, A.J. Opinion: The origin of the cancer stem cell: Current controversies and new insights. Nat. Rev. Cancer 2005, 5, 899-904. [CrossRef] [PubMed]

71. Li, F.; Tiede, B.; Massague, J.; Kang, Y. Beyond tumorigenesis: Cancer stem cells in metastasis. Cell Res. 2007, 17, 3-14. [CrossRef] [PubMed]

72. Dittmar, T.; Nagler, C.; Schwitalla, S.; Reith, G.; Niggemann, B.; Zanker, K.S. Recurrence cancer stem cells-Made by cell fusion? Med. Hypotheses 2009, 73, 542-547. [CrossRef] [PubMed]

73. Lu, X.; Kang, Y. Cell fusion hypothesis of cancer stem cells. In Cell Fusion in Health and Disease. Volume ii: Cell Fusion in Disease, 1st ed.; Dittmar, T., Zänker, K.S., Eds.; Springer Netherlands: Dordrecht, The Netherlands, 2011; pp. 129-140.

74. Houghton, J.M. Bone-marrow-derived cells and cancer-An opportunity for improved therapy. Nat. Rev. Clin. Oncol. 2007, 4, 2-3. [CrossRef] [PubMed]

75. Quintana, E.; Shackleton, M.; Sabel, M.S.; Fullen, D.R.; Johnson, T.M.; Morrison, S.J. Efficient tumour formation by single human melanoma cells. Nature 2008, 456, 593-598. [CrossRef] [PubMed]

76. Zhou, B.B.; Zhang, H.; Damelin, M.; Geles, K.G.; Grindley, J.C.; Dirks, P.B. Tumour-initiating cells: Challenges and opportunities for anticancer drug discovery. Nat. Rev. Drug Discov. 2009, 8, 806-823. [CrossRef] [PubMed]

77. Phillips, T.M.; McBride, W.H.; Pajonk, F. The response of CD24(-/low)/CD44+ breast cancer-initiating cells to radiation. J. Natl. Cancer Inst. 2006, 98, 1777-1785. [CrossRef] [PubMed]

78. Woodward, W.A.; Chen, M.S.; Behbod, F.; Alfaro, M.P.; Buchholz, T.A.; Rosen, J.M. WNT/ $\beta$-catenin mediates radiation resistance of mouse mammary progenitor cells. Proc. Natl. Acad. Sci. USA 2007, 104, 618-623. [CrossRef] [PubMed]

79. Nagler, C.; Zänker, K.S.; Dittmar, T. Cell fusion, drug resistance and recurrence cscs. In Cell Fusion in Health and Disease. Volume II: Cell Fusion in Disease, 1st ed.; Zänker, K.S., Dittmar, T., Eds.; Springer Netherlands: Dordrecht, The Netherlands, 2011; pp. 173-182.

80. Zhang, D.; Wang, Y.; Zhang, S. Asymmetric cell division in polyploid giant cancer cells and low eukaryotic cells. BioMed Res. Int. 2014, 2014, 432652. [CrossRef] [PubMed] 
81. Kawano, N.; Harada, Y.; Yoshida, K.; Miyado, M.; Miyado, K. Role of CD9 in sperm-egg fusion and its general role in fusion phenomena. In Cell Fusions: Regulation and Control, 1st ed.; Larsson, L.-I., Ed.; Springer Netherlands: Dordrecht, The Netherlands, 2010; pp. 171-184.

82. Yi, Y.-J.; Zimmerman, S.W.; Sutovsky, P. Gamete binding and fusion. In Cell Fusions: Regulation and Control, 1st ed.; Larsson, L.-I., Ed.; Springer Netherlands: Dordrecht, The Netherlands, 2010; pp. 185-201.

83. Chen, E.H.; Grote, E.; Mohler, W.; Vignery, A. Cell-cell fusion. FEBS Lett. 2007, 581, 2181-2193. [CrossRef] [PubMed]

84. Horsley, V.; Pavlath, G.K. Forming a multinucleated cell: Molecules that regulate myoblast fusion. Cells Tissues Organs 2004, 176, 67-78. [CrossRef] [PubMed]

85. Buckingham, M. Myogenic progenitor cells and skeletal myogenesis in vertebrates. Curr. Opin. Genet. Dev. 2006, 16, 525-532. [CrossRef] [PubMed]

86. Vignery, A. Osteoclasts and giant cells: Macrophage-macrophage fusion mechanism. Int. J. Exp. Pathol. 2000, 81, 291-304. [CrossRef] [PubMed]

87. Vignery, A. Macrophage fusion: The making of osteoclasts and giant cells. J. Exp. Med. 2005, 202, 337-340. [CrossRef] [PubMed]

88. Kaji, K.; Oda, S.; Miyazaki, S.; Kudo, A. Infertility of CD9-deficient mouse eggs is reversed by mouse CD9, human CD9, or mouse CD81; polyadenylated mrna injection developed for molecular analysis of sperm-egg fusion. Dev. Biol. 2002, 247, 327-334. [CrossRef] [PubMed]

89. Kaji, K.; Oda, S.; Shikano, T.; Ohnuki, T.; Uematsu, Y.; Sakagami, J.; Tada, N.; Miyazaki, S.; Kudo, A. The gamete fusion process is defective in eggs of CD9-deficient mice. Nat. Genet. 2000, 24, 279-282. [CrossRef] [PubMed]

90. Le Naour, F.; Rubinstein, E.; Jasmin, C.; Prenant, M.; Boucheix, C. Severely reduced female fertility in CD9-deficient mice. Science 2000, 287, 319-321. [CrossRef] [PubMed]

91. Miyado, K.; Yamada, G.; Yamada, S.; Hasuwa, H.; Nakamura, Y.; Ryu, F.; Suzuki, K.; Kosai, K.; Inoue, K.; Ogura, A.; et al. Requirement of CD9 on the egg plasma membrane for fertilization. Science 2000, 287, 321-324. [CrossRef] [PubMed]

92. Rubinstein, E.; Ziyyat, A.; Prenant, M.; Wrobel, E.; Wolf, J.P.; Levy, S.; Le Naour, F.; Boucheix, C. Reduced fertility of female mice lacking CD81. Dev. Biol. 2006, 290, 351-358. [CrossRef] [PubMed]

93. Tanigawa, M.; Miyamoto, K.; Kobayashi, S.; Sato, M.; Akutsu, H.; Okabe, M.; Mekada, E.; Sakakibara, K.; Miyado, M.; Umezawa, A.; et al. Possible involvement of CD81 in acrosome reaction of sperm in mice. Mol. Reprod. Dev. 2008, 75, 150-155. [CrossRef] [PubMed]

94. Evans, J.P. Fertilin $\beta$ and other adams as integrin ligands: Insights into cell adhesion and fertilization. Bioessays 2001, 23, 628-639. [CrossRef] [PubMed]

95. Okabe, M.; Adachi, T.; Takada, K.; Oda, H.; Yagasaki, M.; Kohama, Y.; Mimura, T. Capacitation-related changes in antigen distribution on mouse sperm heads and its relation to fertilization rate in vitro. J. Reprod. Immunol. 1987, 11, 91-100. [CrossRef]

96. Inoue, N.; Ikawa, M.; Isotani, A.; Okabe, M. The immunoglobulin superfamily protein izumo is required for sperm to fuse with eggs. Nature 2005, 434, 234-238. [CrossRef] [PubMed]

97. Önel, S.-F.; Dottermusch, C.; Sickmann, A.; Buttgereit, D.; Renkawitz-Pohl, R. Role of the actin cytoskeleton within furmas during drosophila myoblast fusion and first functionally conserved factors in vertebrates. In Cell Fusions: Regulation and Control, 1st ed.; Larsson, L.-I., Ed.; Springer Netherlands: Dordrecht, The Netherlands, 2010; pp. 139-170.

98. Fischbach, K.F.; Linneweber, G.A.; Andlauer, T.F.; Hertenstein, A.; Bonengel, B.; Chaudhary, K. The IRRE cell recognition module (IRM) proteins. J. Neurogenet. 2009, 23, 48-67. [CrossRef] [PubMed]

99. Uluckan, O.; Becker, S.N.; Deng, H.; Zou, W.; Prior, J.L.; Piwnica-Worms, D.; Frazier, W.A.; Weilbaecher, K.N. CD47 regulates bone mass and tumor metastasis to bone. Cancer Res. 2009, 69, 3196-3204. [CrossRef] [PubMed]

100. Kukreja, A.; Radfar, S.; Sun, B.H.; Insogna, K.; Dhodapkar, M.V. Dominant role of CD47-thrombospondin-1 interactions in myeloma-induced fusion of human dendritic cells: Implications for bone disease. Blood 2009, 114, 3413-3421. [CrossRef] [PubMed]

101. Cui, W.; Ke, J.Z.; Zhang, Q.; Ke, H.Z.; Chalouni, C.; Vignery, A. The intracellular domain of CD44 promotes the fusion of macrophages. Blood 2006, 107, 796-805. [CrossRef] [PubMed] 
102. Mensah, K.A.; Ritchlin, C.T.; Schwarz, E.M. RANKl induces heterogeneous DC-STAMPlo and DC-STAMPhi osteoclast precursors of which the DC-STAMPlo precursors are the master fusogens. J. Cell. Physiol. 2010, 223, 76-83. [PubMed]

103. Yagi, M.; Miyamoto, T.; Sawatani, Y.; Iwamoto, K.; Hosogane, N.; Fujita, N.; Morita, K.; Ninomiya, K.; Suzuki, T.; Miyamoto, K.; et al. DC-STAMP is essential for cell-cell fusion in osteoclasts and foreign body giant cells. J. Exp. Med. 2005, 202, 345-351. [CrossRef] [PubMed]

104. Witwicka, H.; Hwang, S.Y.; Reyes-Gutierrez, P.; Jia, H.; Odgren, P.E.; Donahue, L.R.; Birnbaum, M.J.; Odgren, P.R. Studies of OC-STAMP in osteoclast fusion: A new knockout mouse model, rescue of cell fusion, and transmembrane topology. PLOS ONE 2015, 10, e0128275. [CrossRef] [PubMed]

105. Chiu, Y.G.; Ritchlin, C.T. Dc-stamp: A key regulator in osteoclast differentiation. J. Cell. Physiol. 2016. [CrossRef] [PubMed]

106. Pérot, P.; Montgiraud, C.; Lavillette, D.; Mallet, F. A comparative portrait of retroviral fusogens and syncytins. In Cell Fusions: Regulation and Control, 1st ed.; Larsson, L.-I., Ed.; Springer Netherlands: Dordrecht, The Netherlands, 2010; pp. 63-115.

107. Gerbaud, P.; Pidoux, G. Review: An overview of molecular events occurring in human trophoblast fusion. Placenta 2015, 36, S35-S42. [CrossRef] [PubMed]

108. Benirschke, K.; Burton, G.J.; Baergen, R.N. Architecture of normal villous trees. In Pathology of the Human Placenta, 6th ed.; Springer-Verlag: Berlin, Germany; Heidelberg, Germany, 2012; pp. 101-144.

109. Benirschke, K.; Burton, G.J.; Baergen, R.N. Early development of the human placenta. In Pathology of the Human Placenta, 6th ed.; Springer-Verlag: Berlin, Germany; Heidelberg, Germany, 2012; pp. 41-53.

110. Eaton, B.; Contractor, S. In vitro assessment of trophoblast receptors and placental transport mechanisms. In The Human Placenta, 1st ed.; Redman, C.W., Sargent, I.L., Starkey, P.M., Eds.; Blackwell Scientific Publication: London, UK, 1993; pp. 471-503.

111. Ogren, L.; Talamentes, F. The placenta as an endocrine organ: Polypeptides. In The Physiology of Reproduction, 2nd ed.; Knobil, E., Neill, J., Eds.; Raven Press: New York, NY, USA, 1994; pp. 875-945.

112. Bozzuto, G.; Ruggieri, P.; Molinari, A. Molecular aspects of tumor cell migration and invasion. Ann. Ist. Super Sanita. 2010, 46, 66-80. [CrossRef] [PubMed]

113. Blond, J.L.; Beseme, F.; Duret, L.; Bouton, O.; Bedin, F.; Perron, H.; Mandrand, B.; Mallet, F. Molecular characterization and placental expression of HERV-W, a new human endogenous retrovirus family. J. Virol. 1999, 73, 1175-1185. [PubMed]

114. Mi, S.; Lee, X.; Li, X.; Veldman, G.M.; Finnerty, H.; Racie, L.; LaVallie, E.; Tang, X.Y.; Edouard, P.; Howes, S.; et al. Syncytin is a captive retroviral envelope protein involved in human placental morphogenesis. Nature 2000, 403, 785-789. [PubMed]

115. Blaise, S.; de Parseval, N.; Heidmann, T. Functional characterization of two newly identified human endogenous retrovirus coding envelope genes. Retrovirology 2005, 2, 19. [CrossRef] [PubMed]

116. Larsson, L.I.; Bjerregaard, B.; Talts, J.F. Cell fusions in mammals. Histochem. Cell Biol. 2008, 129, 551-561. [CrossRef] [PubMed]

117. Jahn, R.; Lang, T.; Sudhof, T.C. Membrane fusion. Cell 2003, 112, 519-533. [CrossRef]

118. Chen, E.H.; Olson, E.N. Unveiling the mechanisms of cell-cell fusion. Science 2005, 308, 369-373. [CrossRef] [PubMed]

119. Hu, C.; Ahmed, M.; Melia, T.J.; Sollner, T.H.; Mayer, T.; Rothman, J.E. Fusion of cells by flipped snares. Science 2003, 300, 1745-1749. [CrossRef] [PubMed]

120. Caceres, M.; Thomas, J.W. The gene of retroviral origin syncytin 1 is specific to hominoids and is inactive in old world monkeys. J. Hered. 2006, 97, 100-106. [CrossRef] [PubMed]

121. Lander, E.S.; Linton, L.M.; Birren, B.; Nusbaum, C.; Zody, M.C.; Baldwin, J.; Devon, K.; Dewar, K.; Doyle, M.; FitzHugh, W.; et al. Initial sequencing and analysis of the human genome. Nature 2001, 409, 860-921. [CrossRef] [PubMed]

122. Maliniemi, P.; Vincendeau, M.; Mayer, J.; Frank, O.; Hahtola, S.; Karenko, L.; Carlsson, E.; Mallet, F.; Seifarth, W.; Leib-Mosch, C.; et al. Expression of human endogenous retrovirus-w including syncytin-1 in cutaneous t-cell lymphoma. PLoS ONE 2013, 8, e76281. [CrossRef] [PubMed]

123. Yu, H.; Liu, T.; Zhao, Z.; Chen, Y.; Zeng, J.; Liu, S.; Zhu, F. Mutations in 3'-long terminal repeat of HERV-W family in chromosome 7 upregulate syncytin-1 expression in urothelial cell carcinoma of the bladder through interacting with C-MYB. Oncogene 2014, 33, 3947-3958. [CrossRef] [PubMed] 
124. Strissel, P.L.; Ruebner, M.; Thiel, F.; Wachter, D.; Ekici, A.B.; Wolf, F.; Thieme, F.; Ruprecht, K.; Beckmann, M.W.; Strick, R. Reactivation of codogenic endogenous retroviral (ERV) envelope genes in human endometrial carcinoma and prestages: Emergence of new molecular targets. Oncotarget. 2012, 3, 1204-1219. [CrossRef] [PubMed]

125. Strick, R.; Ackermann, S.; Langbein, M.; Swiatek, J.; Schubert, S.W.; Hashemolhosseini, S.; Koscheck, T.; Fasching, P.A.; Schild, R.L.; Beckmann, M.W.; et al. Proliferation and cell-cell fusion of endometrial carcinoma are induced by the human endogenous retroviral syncytin-1 and regulated by TGF- $\beta$. J. Mol. Med. 2007, 85, 23-38. [CrossRef] [PubMed]

126. Sun, Y.; Ouyang, D.Y.; Pang, W.; Tu, Y.Q.; Li, Y.Y.; Shen, X.M.; Tam, S.C.; Yang, H.Y.; Zheng, Y.T. Expression of syncytin in leukemia and lymphoma cells. Leuk. Res. 2010, 34, 1195-1202. [CrossRef] [PubMed]

127. Yi, J.M.; Kim, H.M.; Kim, H.S. Expression of the human endogenous retrovirus HERV-W family in various human tissues and cancer cells. J. Gen. Virol. 2004, 85, 1203-1210. [CrossRef] [PubMed]

128. Larsen, J.M.; Christensen, I.J.; Nielsen, H.J.; Hansen, U.; Bjerregaard, B.; Talts, J.F.; Larsson, L.I. Syncytin immunoreactivity in colorectal cancer: Potential prognostic impact. Cancer Lett. 2009, 280, 44-49. [CrossRef] [PubMed]

129. Larsson, L.I.; Holck, S.; Christensen, I.J. Prognostic role of syncytin expression in breast cancer. Hum. Pathol. 2007, 38, 726-731. [CrossRef] [PubMed]

130. Bjerregaard, B.; Holck, S.; Christensen, I.J.; Larsson, L.I. Syncytin is involved in breast cancer-endothelial cell fusions. Cell. Mol. Life Sci. 2006, 63, 1906-1911. [CrossRef] [PubMed]

131. Yi, J.M.; Lee, W.H.; Kim, H.M.; Kim, H.S. Identification of new endogenous retroviral sequences belonging to the HERV-W family in human cancer cells. Intervirology 2001, 44, 333-338. [CrossRef] [PubMed]

132. Kudo, Y.; Boyd, C.A. Changes in expression and function of syncytin and its receptor, amino acid transport system B(0) (ASCT2), in human placental choriocarcinoma bewo cells during syncytialization. Placenta 2002, 23, 536-541. [CrossRef] [PubMed]

133. Borges, M.; Bose, P.; Frank, H.G.; Kaufmann, P.; Potgens, A.J. A two-colour fluorescence assay for the measurement of syncytial fusion between trophoblast-derived cell lines. Placenta 2003, 24, 959-964. [CrossRef]

134. Esnault, C.; Priet, S.; Ribet, D.; Vernochet, C.; Bruls, T.; Lavialle, C.; Weissenbach, J.; Heidmann, T. A placenta-specific receptor for the fusogenic, endogenous retrovirus-derived, human syncytin-2. Proc. Natl. Acad. Sci. USA 2008, 105, 17532-17537. [CrossRef] [PubMed]

135. Strick, R.; Beckmann, M.W.; Strissel, P.L. Cell-cell fusions and human endogenous retroviruses in cancer. In Cell Fusions: Regulation and Control, 1st ed.; Larsson, L.-I., Ed.; Springer Netherlands: Dordrecht, The Netherlands, 2010; pp. 395-426.

136. Li, J.; Lee, A.S. Stress induction of GRP78/BIP and its role in cancer. Curr. Mol. Med. 2006, 6, 45-54. [CrossRef] [PubMed]

137. Fradet, S.; Pierredon, S.; Ribaux, P.; Epiney, M.; Shin Ya, K.; Irion, O.; Cohen, M. Involvement of membrane GRP78 in trophoblastic cell fusion. PLoS ONE 2012, 7, e40596. [CrossRef] [PubMed]

138. Cohen, M.; Ribaux, P.; Epiney, M.; Irion, O. Role of prostate apoptosis response 4 in translocation of GRP78 from the endoplasmic reticulum to the cell surface of trophoblastic cells. PLoS ONE 2013, 8, e80231. [CrossRef] [PubMed]

139. Chang, C.; Chen, P.T.; Chang, G.D.; Huang, C.J.; Chen, H. Functional characterization of the placental fusogenic membrane protein syncytin. Biol. Reprod. 2004, 71, 1956-1962. [PubMed]

140. Gong, R.; Peng, X.; Kang, S.; Feng, H.; Huang, J.; Zhang, W.; Lin, D.; Tien, P.; Xiao, G. Structural characterization of the fusion core in syncytin, envelope protein of human endogenous retrovirus family W. Biochem. Biophys. Res. Commun. 2005, 331, 1193-1200. [PubMed]

141. Chernomordik, L.V.; Kozlov, M.M. Mechanics of membrane fusion. Nat. Struct. Mol. Biol. 2008, 15, 675-683. [PubMed]

142. Riddell, M.R.; Winkler-Lowen, B.; Jiang, Y.; Davidge, S.T.; Guilbert, L.J. Pleiotropic actions of forskolin result in phosphatidylserine exposure in primary trophoblasts. PLOS ONE 2013, 8, e81273.

143. Takeda, M.; Leser, G.P.; Russell, C.J.; Lamb, R.A. Influenza virus hemagglutinin concentrates in lipid raft microdomains for efficient viral fusion. Proc. Natl. Acad. Sci. USA 2003, 100, 14610-14617. [PubMed]

144. Suomalainen, M. Lipid rafts and assembly of enveloped viruses. Traffic 2002, 3, 705-709. [CrossRef] [PubMed] 
145. Langbein, M.; Strick, R.; Strissel, P.L.; Vogt, N.; Parsch, H.; Beckmann, M.W.; Schild, R.L. Impaired cytotrophoblast cell-cell fusion is associated with reduced syncytin and increased apoptosis in patients with placental dysfunction. Mol. Reprod. Dev. 2008, 75, 175-183. [CrossRef] [PubMed]

146. Chen, C.P.; Wang, K.G.; Chen, C.Y.; Yu, C.; Chuang, H.C.; Chen, H. Altered placental syncytin and its receptor ASCT2 expression in placental development and pre-eclampsia. BJOG 2006, 113, 152-158. [CrossRef] [PubMed]

147. Lee, X.; Keith, J.C., Jr.; Stumm, N.; Moutsatsos, I.; McCoy, J.M.; Crum, C.P.; Genest, D.; Chin, D.; Ehrenfels, C.; Pijnenborg, R.; et al. Downregulation of placental syncytin expression and abnormal protein localization in pre-eclampsia. Placenta 2001, 22, 808-812. [CrossRef] [PubMed]

148. Zhou, Y.; Mohan, A.; Moore, D.C.; Lin, L.; Zhou, F.L.; Cao, J.; Wu, Q.; Qin, Y.X.; Reginato, A.M.; Ehrlich, M.G.; et al. SHP2 regulates osteoclastogenesis by promoting preosteoclast fusion. FASEB J. 2015, 29, 1635-1645. [CrossRef] [PubMed]

149. Skeel, R.T.; Khleif, S. Handbook of Cancer Chemotherapy, 8th ed.; Lippincott Williams and Wilkins: Philadelphia, PA, USA, 2011.

150. Gong, J.; Koido, S. Cell fusion and dendritic cell-based vaccines. In Cell Fusions: Regulation and Control, 1st ed.; Larsson, L.-I., Ed.; Springer Netherlands: Dordrecht, The Netherlands, 2010; pp. 315-350.

151. Koido, S.; Hara, E.; Homma, S.; Ohkusa, T.; Gong, J.; Tajiri, H. Cancer immunotherapy by fusions of dendritic cells and tumor cells. Immunotherapy 2009, 1, 49-62. [CrossRef] [PubMed]

152. Steinman, R.M. The dendritic cell system and its role in immunogenicity. Annu. Rev. Immunol. 1991, 9, 271-296. [CrossRef] [PubMed]

153. Steinman, R.M. Dendritic cells and the control of immunity: Enhancing the efficiency of antigen presentation. Mt. Sinai J. Med. 2001, 68, 160-166. [PubMed]

154. Homma, S.; Matai, K.; Irie, M.; Ohno, T.; Kufe, D.; Toda, G. Immunotherapy using fusions of autologous dendritic cells and tumor cells showed effective clinical response in a patient with advanced gastric carcinoma. J. Gastroenterol. 2003, 38, 989-994. [CrossRef] [PubMed]

155. Kjaergaard, J.; Shimizu, K.; Shu, S. Electrofusion of syngeneic dendritic cells and tumor generates potent therapeutic vaccine. Cell. Immunol. 2003, 225, 65-74. [CrossRef] [PubMed]

156. Trevor, K.T.; Cover, C.; Ruiz, Y.W.; Akporiaye, E.T.; Hersh, E.M.; Landais, D.; Taylor, R.R.; King, A.D.; Walters, R.E. Generation of dendritic cell-tumor cell hybrids by electrofusion for clinical vaccine application. Cancer Immunol. Immunother. 2004, 53, 705-714. [CrossRef] [PubMed]

157. Scott-Taylor, T.H.; Pettengell, R.; Clarke, I.; Stuhler, G.; La Barthe, M.C.; Walden, P.; Dalgleish, A.G. Human tumour and dendritic cell hybrids generated by electrofusion: Potential for cancer vaccines. Biochim. Biophys. Acta 2000, 1500, 265-279. [CrossRef]

158. Hiraoka, K.; Yamamoto, S.; Otsuru, S.; Nakai, S.; Tamai, K.; Morishita, R.; Ogihara, T.; Kaneda, Y. Enhanced tumor-specific long-term immunity of hemagglutinating [correction of hemaggluttinating] virus of Japan-mediated dendritic cell-tumor fused cell vaccination by coadministration with CpG oligodeoxynucleotides. J. Immunol. 2004, 173, 4297-4307. [CrossRef] [PubMed]

159. Phan, V.; Errington, F.; Cheong, S.C.; Kottke, T.; Gough, M.; Altmann, S.; Brandenburger, A.; Emery, S.; Strome, S.; Bateman, A.; et al. A new genetic method to generate and isolate small, short-lived but highly potent dendritic cell-tumor cell hybrid vaccines. Nat. Med. 2003, 9, 1215-1219. [CrossRef] [PubMed]

(C) 2016 by the authors; licensee MDPI, Basel, Switzerland. This article is an open access article distributed under the terms and conditions of the Creative Commons Attribution (CC-BY) license (http://creativecommons.org/licenses/by/4.0/). 